\title{
The Psychoprophylactic Method of Painless Childbirth in Socialist Czechoslovakia: from State Propaganda to Activism of Enthusiasts
}

\author{
EMA HREŠANOVÁ * \\ Department of Sociology, University of West Bohemia, Univerzitni 8, \\ 30614 Plzen, Czech Republic
}

\begin{abstract}
This paper explores the history of the 'psychoprophylactic method of painless childbirth' in socialist Czechoslovakia, in particular, in the Czech and Moravian regions of the country, showing that it substantially differs from the course that the method took in other countries. This non-pharmacological method of pain relief originated in the USSR and became well known as the Lamaze method in western English-speaking countries. Use of the method in Czechoslovakia, however, followed a very different path from both the West, where its use was refined mainly outside the biomedical frame, and the USSR, where it ceased to be pursued as a scientific method in the 1950s after Stalin's death. The method was imported to Czechoslovakia in the early 1950s and it was politically promoted as Soviet science's gift to women. In the 1960s the method became widespread in practice but research on it diminished and, in the 1970s, its use declined too. However, in the 1980s, in the last decade of the Communist regime, the method resurfaced in the pages of Czechoslovak medical journals and underwent an exciting renaissance, having been reintroduced by a few enthusiastic individuals, most of them women. This article explores the background to the renewed interest in the method while providing insight into the wider social and political context that shaped socialist maternity and birth care in different periods.
\end{abstract}

Keywords: Eastern bloc, Socialist birth care, Maternity care, Lamaze method, Natural childbirth, Childbirth education

* Email address for correspondence: ehresano@kss.zcu.cz

This paper is part of the research project GAČR P404/11/P089 funded by the Czech Science Foundation. I wish to thank Dr Paula Michaels for her insightful comments and tremendous help, Dr Pavel Čepický, Dr Marie Pečená, Mgr Květa Ludvíková, Ivana Nyčová (a librarian in the Archive of the Institute for the Care of Mother and Child in Prague), Dr Tereza Stöckelová, Dr Cynthia Paces, Dr Petr Roubal, Dr Pavel Sitek and, especially, Dr Martin Hříbek. My acknowledgements further go to the Fulbright Commission in the Czech Republic, Monash University and the Group of Eight, Australia. 


\section{Introduction}

For millennia women gave birth in pain. Soviet science sought to change this forever. In the late 1940s, Soviet scientists invented a new non-pharmacological method called the 'psychoprophylactic method of painless childbirth' (PPM), which later became well known as the Lamaze method in the West. ${ }^{1}$ This gift of Soviet science to the women of the world was based on the assumption that it was possible to eliminate the sensation of bodily pain during labour by training the mind of a pregnant woman before she gives birth. ${ }^{2}$

In brief, the argument is that the birthing process is controlled by the cerebral cortex, which plays a role in the perception of pain. Pain, it was therefore claimed, is not an essential part of labour as, in reality, it is the product of conditioned reflexes, and these, in accordance with Pavlov's theory of conditioned reflexes, are acquired and temporary. PPM acts to 'reprogramme' these conditioned reflexes and create new and positive ones that prevent the perception of pain during labour and delivery. PPM training draws on a range of methods, including antenatal education, breathing techniques, suggestion and massage. ${ }^{3}$

While PPM originated in the USSR, it became famous worldwide. There are a number of studies describing the development of the psychoprophylactic method in the former Soviet Union ${ }^{4}$ and France ${ }^{5}$ or depicting the history of what in the Anglo-American West was known as the 'Lamaze method' ${ }^{6}$ In contrast, studies of PPM in other countries of the former Eastern bloc are rare and are not generally available internationally. ${ }^{7}$

By unearthing the story of Czechoslovakia's experience with psychoprophylaxis, this article contributes to the vibrant discussion among historians about the diverse national experiences with this method and what this says about East and West during the Cold War. In Czechoslovakia, PPM followed a very different path from that taken in the West. In the United States and Western Europe, it was further refined over time and was promoted alongside biomedical approaches. In the United States, it gained popularity thanks to a grassroots initiative, while, in France, women's communist organisations promoted the

\footnotetext{
${ }^{1}$ Paula Michaels, Lamaze: An International History (New York: Oxford University Press, 2014), 8.

2 Dušan Brucháč, Teória a prax zbezbolestňovania pôrodu (Bratislava: Vydavateĺstvo Slovenskej Akadémie vied, 1963), 8-9: 80.

${ }^{3}$ Anatolii Petrovich Nikolaev, Bezbolestný porod. Př́spěvky $k$ theorii a praxi (Praha: Státní zdravotnické nakladatelství, 1955); Leon Chertok, Psychosomatické metody bezbolestného porodu. Historie, teorie a praxe. Výbor (Praha: Státní zdravotnické nakladatelství, 1966), 43-51; John Bell, 'Giving Birth to the New Soviet Man: Politics and Obstetrics in the USSR', Slavic Review, 40, 1 (1981), 1-16.

${ }^{4}$ Chertok, ibid., 40-3; Bell, ibid.; Paula Michaels, 'Childbirth Pain Relief and the Soviet Origins of the Lamaze Method', NCEEER Occasional Paper (2007), 1-31. http://www.ucis.pitt.edu/nceeer/2007_821-10g_Mi chaels.pdf (accessed 22 July 2014).

5 Paula Michaels, 'Comrades in the Labor Room: The Lamaze Method of Childbirth Preparation and France's Cold War Home Front, 1951-1957’, The American Historical Review, 115, 4 (2010), 1031-60; Paula Michaels, 'A Chapter from Lamaze History: Birth Narrative and Authoritative Knowledge in France, 1952-57', Journal of Perinatal Education, 19, 2 (2010), 35-43; Caroline Gutmann, The Legacy of Dr Lamaze: The Story of the Man who Changed Childbirth, Bruce Benderson (trans.) (New York: St Martin's Press, 2001); see also Niels Beck, Elizabeth Geden and Gerald Brouder, 'Preparation for Labor: a Historical Perspective', Psychosomatic Medicine, 41, 3 (1979), 243-58; Marianne Caron-Leulliez and Jocelyn George, L'accouchement sans douleur: Histoire d'une révolution oubliée (Paris: Editions d'Atelier, 2004); Marilène Vuille, 'Le militantisme en faveur de l'accouchement sans douleur', Nouvelles questions féministes, 24, 3 (2005), 50-67.

${ }^{6}$ Michaels, 'Comrades in the Labor Room', ibid.; Michaels, 'A Chapter from Lamaze History', ibid., 35-43; Beck, Geden and Brouder, ibid.

${ }^{7}$ Many studies on PPM were conducted in Poland and Hungary; eg. E. Dabrowski, 'Dotychczasowe Wyniki Psychoprofilaktyki Bólów Porodowych', Polski Tygodnik Lekarski, 11, 42 (1956), 1786-90; L. Rakos, 'Lessening of Pain in Labor by the Psychoprophylactic Method', Orvosi hetilap, 100 (1959), 1366-9.
} 
method. But the Czechoslovak experience was also very different from the path that PPM took in the USSR. In the Soviet Union, all Soviet childbirth facilities were issued an official order to use the method by the Ministry of Public Health on 13 February $1951 .^{8}$ Soviet medical experts, however, abandoned interest in the method after Stalin's death when it was no longer promoted by the political authorities. ${ }^{9}$ In contrast, in Czechoslovakia, there was an exciting 'rediscovery' of PPM in the last decade of the Communist regime in the 1980s when it was reintroduced by a few enthusiastic individuals, most of whom, unlike the pioneers of PPM, were women. The history of PPM in Czechoslovakia offers a vivid case study in how political and cultural factors have an impact on medical science and medical practices. It illustrates the various historical paths that the method took within an Eastern bloc dominated by the USSR and provides insight into the wider social and political context that shaped the state-socialist birth-care system in different periods.

This paper aims to reconstruct the story of PPM in state-socialist Czechoslovakia and to identify the key factors that affected its use and development. I trace the history of PPM from the early 1950s, when it was introduced into Czechoslovakia, up to 1990, when massive social and political changes began to occur in the wake of the Velvet Revolution. Given my wider objective of understanding current changes in the Czech birth-care system, particularly ones that relate to the competing discourses surrounding childbirth, I focus here solely on professional medical and political debates and do not address the equally important question of women's birth experiences.

This study is part of a wider project on the natural childbirth movement in the Czech Republic which studies the concept of natural childbirth as a complex set of different ideas of various origin and tries to identify and track the different paths and permutations these ideas have taken. ${ }^{10}$ I approach the history of the psychoprophylactic method as one of the ideas associated with 'natural' childbirth in the Czech Republic today; and, for these reasons, my analysis primarily focuses on the development of PPM in the Czech and Moravian regions of the Czechoslovak state. ${ }^{11}$ Developed within the medical setting, but elaborated further by natural childbirth activists, PPM is one of many systems of thought and practices that are linked to both medicalised and 'alternative' discourses on childbirth management. Untangling its history may help us to understand what sets these discourses apart and in what ways they are linked and intertwined.

I shall begin by providing essential background information on the Czechoslovak healthcare system into which PPM was introduced from Moscow. I then chronologically tell the story of Czechoslovak PPM in three parts, focusing, in particular, on the 1950s and the 1980s. I analyse the formative 1950s in detail in order to show the political background to the introduction of PPM. In the 1960s, the method became widespread in practice but research on PPM declined, while, in the 1970s, psychoprophylaxis was a little used

\footnotetext{
${ }^{8}$ Order No. 142, 'O vnedrenii v praktiku psikhoprofilaktiki bolei v rodakh'; Michaels, op. cit. (note 1), 42-3: 169; Michaels, op. cit. (note 4), 4.

${ }^{9}$ Michaels, op. cit. (note 1), 78; Michaels, 'Comrades in the Labor Room', op. cit. (note 5), 1053; Bell, op. cit. (note 3).

${ }^{10} \mathrm{I}$ build here on the analysis of newspaper and magazine articles, published and unpublished research reports archived at the Institute for the Care of Mother and Child in Prague [ICMC] and in-depth interviews with leading experts on PPM.

${ }^{11}$ In this study, I prefer to use the adjective 'Czechoslovak', derived from the country's name, instead of indicating researchers' particular national identities, as national identity could be very complex within this multinational state. I do not pursue Slovak links in depth here because of several important historical differences which need to be explored more in a separate study. Slovakia formed a separate state during the Second World War and this had consequences for its health-care system.
} 
practice. At the beginning of the 1980s, the method received a new impetus and I explain what events and factors lay behind its rebirth.

\section{Changes in the Health-Care System after the Second World War}

The Czechoslovak health-care system underwent a profound reorganisation in the postwar period, especially after the Communist coup in February 1948. The Communist state nationalised all the hospitals, sanatoriums, health spas and part of the pharmaceutical industry. ${ }^{12}$ It set up a comprehensive social-insurance system that, among other things, expanded the existing maternity insurance schemes. ${ }^{13}$ The most important reform was the 'Nedvěd Plan', designed by a group of communist health experts headed up by Dr Miloš Nedvěd during the Second World War. It proposed to build a unified and integrated healthcare system, financed and controlled by the state, in which health care would be free of charge for citizens at the point of consumption. ${ }^{14}$ In these years, new health-related laws were introduced and a new network of district and regional health facilities was built. These national health institutions became the pillars of the nationalised health-care system. ${ }^{15}$

In tune with these reforms, the government also started to build a national network of antenatal clinics under new legislation introduced in $1947 .{ }^{16}$ But women were not really interested in going to these clinics. This posed a problem because the antenatal clinics were designed not just to prevent disease and educate pregnant women, but also to monitor their numbers and probe women's social and family background $;{ }^{17}$ thus they were to serve as a tool of the state's biopolitics. ${ }^{18}$ As there was a shortage of skilled obstetricians and gynaecologists to staff the new Czech maternity-care system, most of these clinics had to be run by general practitioners, whose 'insufficient knowledge of the subject' was found to be the main reason why the antenatal clinics did not appeal to women. ${ }^{19}$

There was a general shortage of physicians in the late 1940s because Czech universities had been shut down by the Nazi regime at the beginning of the war. ${ }^{20}$ Midwives were the

12 Alena Heitlinger, Reproduction, Medicine and the State (New York: St Martin's Press, 1987), 75; P. Svobodný, 'Propagace socialistického zdravotnictví v rámci komunistické propagandy (1945-52)', in H. Mášová, E. Křížová and P. Svobodný (eds), České zdravotnictví, vize a skutečnost. Složité peripetie od plánů k realizaci (Praha: Univerzita Karlova v Praze, 2005), 112.

13 The development of the country's universal health-care system, which provided care free of charge to everyone on the basis of citizenship (instead of insurance), was fully completed in 1966 when the act 'On the Health Care of the People' was passed. Heitlinger notes that similar legislation was passed in the USSR in 1969 and in other countries of the Communist bloc; Heitlinger, ibid., 76; Svobodný, ibid., 112.

14 Heitlinger, op. cit. (note 12), 75.

15 Svobodný, op. cit. (note 12), 112; Heitlinger, op. cit. (note 12), 76; J. Rákosník, 'Převzetí sovětského modelu sociální správy v Československu v letech 1950-1956', in Z. Kárník et al. (eds), Bolševismus, komunismus a radikální socialismus v Československu, Vol. 6 (Praha: Dokořán, Ústav pro soudobé dějiny AV ČR, 2009), 174-89.

16 In 1948, there were only 181 antenatal clinics, while, by 1952, their number increased to 891. Zdeněk Štembera, Historie české perinatologie (Praha: Jessenius Maxdorf, 2004), 45.

17 Ibid..

18 This Foucaultian term refers to an effort '... to rationalize the problems presented to governmental practice by the phenomena characteristic of a group of living human beings constituted as a population ... ' Michel Foucault, Ethics: Subjectivity and Truth, P. Rabinow (ed.), R. Hurley (trans.) (New York: The New Press, 1997), 73.

19 Štembera, op. cit. (note 16), 40. All translations from Czech are mine.

20 Thus, in 1951, there were only 326 physicians working in the field of maternity and birth care per 185570 live childbirths, but only 121 were qualified in obstetrics. Czech Statistical Office, 'Population change - Czech Republic: 1919-2014 (absolute figures)', Czech Demographic Handbook - 2014 (Praha: Czech Statistical Office, 2015). https://www.czso.cz/documents/10180/20548157/130055150105a.pdf/1ca4f06a-f504-4b4a-981b -18716 da63942? version=1.0 (accessed 1 December 2015); Štembera, op. cit. (note 16), 55. In comparison, in 
main birth-care providers, along with general practitioners. In the first years after the war, most women still gave birth at home with the assistance of independent midwives. But Act No. 248 'On Regional Midwives', introduced in October 1948, attached midwives to the District Institutes of National Health (OÚNZ) and assigned them health-related 'advisory work', including attending the home births of women who were not entitled to national health insurance. ${ }^{21}$

From 1945 to 1948, there was a sharp increase in the number of hospital births as new maternity wards were built and, with the move from home to hospital, there was a concomitant rise in the use of obstetric anaesthesia. Hospital births doubled and, by 1948, they accounted for 44.4 per cent of all births. ${ }^{22}$ Amid the continuing expansion and administrative transformation of maternity care after 1948, hospital births reached 70 per cent of all births in $1951,{ }^{23}$ and, by 1955 , the figure was more than 92 per cent. ${ }^{24}$ During this time various pharmaceutical methods for relieving the pain of labour were available in most maternity hospitals. Trichloroethylene, an inhaled analgesic, was one of the most common ones and it was available for use at almost every maternity ward. ${ }^{25}$ Unlike in the USSR, where drug shortages led to the exploration of psychological methods for relieving labour pain, ${ }^{26}$ Czechoslovak obstetricians were not encouraged to seek nonpharmacological methods of pain relief; instead, they conducted studies to determine which were the best and safest analgesics and experimented with using them in various combinations. $^{27}$

\section{The 1950s: PPM Arrives}

In the autumn of 1950, three clinical researchers and members of the Communist Party - obstetricians Josef Lukáš and Miroslav Vojta and paediatrician Kamil Kubát - joined a three-month expedition by twenty-four leading experts from the Communist bloc to the Soviet Union, where they spent time in Soviet hospitals to learn about a new method of labour-pain relief: the psychoprophylactic method of painless childbirth. ${ }^{28}$ Soviet professor M.S. Malinovski and his colleague Dr V.N. Shishkova gave the visiting experts a tour of several maternity hospitals in Moscow, where they studied the new method in detail. ${ }^{29}$ The Czech delegation was greatly impressed. Lukáš wrote the first article introducing it to Czechoslovak gynaecologists, ${ }^{30}$ but it was Vojta who became the method's main proponent when he returned home.

2013 there were 2512 obstetricians and gynaecologists per 106751 childbirths. Zdravotnická ročenka $\check{C} R 2013$ (Praha: Ústav zdravotnických informací a statistiky ČR, 2014), 184.

21 Štembera, op. cit. (note 16), 44. In 1965, midwives were officially renamed 'obstetric nurses'. Ema Hrešanová, Kultury dvou porodnic: Etnografická studie (Plzeň: Západočeská univerzita, 2008), 130.

22 Stembera, op. cit. (note 16), 39.

23 Ibid., 53.

24 Ibid., 67.

25 Antonín Pařízek, 'Historický vývoj porodnické analgezie a anestezie v České republice', in A. Pařízek et al., Porodnická analgezie a anestezie (Praha: Grada Publishing, 2002), 43-8.

${ }^{26}$ Paula Michaels, 'Pain and blame: psychological approaches to obstetric pain, 1950-1980', in E. Cohen et al. (eds), Knowledge and Pain (Amsterdam, New York: Rodopi, 2012), 234; Michaels, op. cit. (note 1), 45; Michaels, op. cit. (note 4), 7-13.

27 Štembera, op. cit. (note 16), 65.

${ }^{28}$ Miroslav Vojta, 'Zavedení methodiky psychoprofylaktické př́ípravy bezbolestného porodu v porodnických ústavech', accession number ZZ-5 (unpublished research report: Ústav pro péči o matku a dítě, Praha, 1952); see also Štembera, op. cit. (note 16), 60.

29 Vojta, ibid..

30 Josef Lukáš, 'Psychoprofylaktická příprava k bezbolestnému porodu', Československá gynaekologie, 16, 13 (1951), 158-65. 
Vojta's first impressions of Soviet maternity hospitals were probably not as positive as his later publications and active involvement in promoting the method suggest. Zdeněk Štembera, a perinatologist who once worked with Vojta, ${ }^{31}$ wrote that, in the first letters Vojta sent to his home institution in Prague, he expressed horror at the appalling conditions in Soviet hospitals: 'People [ie. doctors] go into the operating theatres and delivery rooms in their boots, while blood flows in streams. ${ }^{32}$ This shock was soon replaced by a compulsory enthusiasm. Štembera suggests that Vojta's change in attitude might have been inspired by a week of alleged 'training' at Dobříš Castle 'offered' to everyone who had participated in the trip after they returned. According to Štembera, the participants had to hand over all their personal or other notes to the authorities and were instructed on how to properly interpret what they had seen in the USSR and how to utilise their findings 'in a broader historical context'. ${ }^{33}$ After their debriefing, Vojta and Lukáš not only promoted psychoprophylaxis as a progressive method of pain relief in labour, but they took the further, political step of denouncing the Prague school of obstetrics as being in the grip of bourgeois ideology and in need of intellectual and ideological overhaul. ${ }^{34}$

The professional activities of Vojta and Lukáš were supported at the highest political levels. Shortly after becoming a supporter of PPM, Vojta became editor-in-chief of the leading journal Československá gynaekologie [Czechoslovak Gynaecology]. In this prominent position, he could ensure that adequate space was given to the work of Soviet authors. Both doctors were, moreover, able to use their influential positions at research institutions to promote wider social and political changes in the health-care system as a whole and implement the political programme of building a healthy socialist society. ${ }^{35}$

Building on the work of his Soviet colleagues I.Z. Vel'vovskii and A.P. Nikolaev, Vojta presented PPM as the perfect physiological method for eliminating pain during labour and delivery. He adopted the Soviet line on how PPM worked, explaining that labour pain was a consequence of ill-minded folk beliefs about the painfulness of the birthing process; childbirth itself could not be painful, as it is just a matter of contractions of the uterus muscle, and contractions of other muscles do not hurt. ${ }^{36}$ Vojta also highlighted the other alleged benefits of PPM, claiming that it sped up labour, minimised the potential for pathology and nurtured 'health-care providers in maintaining a moral [ie. humane] approach to women giving birth'. ${ }^{37}$

Vojta conducted his research on PPM at the Institute for the Care of Mother and Child in Prague (ICMC), which was founded in 1951 as the first of twenty-six new research institutes in the country. Two clinics - the 3rd Gynaecological-Obstetrical Clinic and the Clinic for Newborn Care in Prague-Podolí - were merged to create a unique environment

31 Zdeněk Štembera is considered to be one of the founding figures of Czech perinatology who closely collaborated with the World Health Organisation. Štembera, op. cit. (note 16), 156. His historical study of Czech perinatology builds on an extensive analysis of medical sources as well as on personal experience.

32 Ibid., 60.

33 Ibid.

34 Ibid.

35 Ibid., 60-1.

${ }^{36}$ Miroslav Vojta, 'Psychoprofylaktická příprava bezbolestného porodu a další statě k "bezbolestnému porodu"', accession number ZZ-22 (unpublished research report: Ústav pro péči o matku a dítě, Praha); Miroslav Vojta, 'K otázce odstraňování bolestí při porodu', Praktický lékař, 33 (1953), 100-1. Cf. also Bell, op. cit. (note 3), 8; Maya Haber, 'Concealing Labor Pain. The Evil Eye and the Psychoprophylactic Method of Painless Childbirth in Soviet Russia', Kritika: Explorations in Russian and Eurasian History, 14, 3 (2013), 535-59.

37 Vojta, 'Psychoprofylaktická př́prava', ibid., 10. 
in which obstetricians and paediatricians were able to collaborate with each other. ${ }^{38}$ The ICMC became a centre of national research, where key studies on maternity and neonatal care, including research on PPM, have been conducted since its foundation to the present day. Vojta was the main researcher responsible for the implementation of PPM and for studying its efficacy. His team, whose members included Dr Havránek and Dr Horský, started to run PPM courses at the ICMC in June 1951. Over the last six months of 1951, they organised 360 lessons in PPM in which seventy-two pregnant women took part, each woman attending five to eight lessons. The women who participated in these first courses were volunteers, mostly white-collar workers, and were described as "neurotic in type'. ${ }^{39}$ Pavlovian neuropsychology, which psychoprophylactic theory invoked to explain how it worked, distinguished several types of central nervous systems ${ }^{40}$ four of which were of particular interest to PPM: (1) strong/balanced and reserved; (2) strong/balanced and active; (3) strong/unbalanced; and (4) weak (ie., neurotic). In theory, identifying a woman's nervous 'temperament' was believed to be crucial to preparing her effectively for labour, but, in practice, the Czechoslovak researchers did not try to identify which of these categories the women belonged to when they recruited them. ${ }^{41}$ They nonetheless drew conclusions similar to their Soviet colleagues: women of different temperaments needed to practise PPM-related exercises, which they had to perform in their sleep, for differing lengths of time. If the women did not practise a sleep duration suited to their particular temperament, the lesson had no positive effects. The researchers concluded that this was why eleven out of seventy-two women in their first research sample had to have a Caesarean section. Two-thirds of the women allegedly experienced painless childbirth, with only slight feelings of pain. These were women who had usually managed to fall asleep during the lessons. PPM failed in the case of women who had difficulty attaining a state of relaxation sufficient to fall asleep during the lessons. The researchers believed that this failure spoke to their own inability to design courses tailored to women's temperament types. ${ }^{42}$ Assuming that the Soviet researchers were right, that women with a stronger and more balanced nervous system experienced greater relief with PPM, then the poor results of Czech researchers could only be attributed to a prevalence of 'weak' nervous types among the research subjects. ${ }^{43}$ Subsequent research tried to take greater account of different nervous types. ${ }^{44}$

Despite the fact that the efficacy of the PPM courses was low, especially in comparison to contemporary Soviet studies, which reported a 70-96 per cent rate of success, ${ }^{45}$ researchers at the ICMC deemed the method suitable for use in the Czechoslovak health system and recommended its implementation at Czechoslovak hospitals. However, it first needed substantial modifications. Vojta argued that local doctors had to contend with the 'different psychology of Czech women', as he put it, and '... the different way in which

\footnotetext{
38 Štembera, op. cit. (note 16), 52.

39 Vojta, 'Psychoprofylaktická př́íprava', op. cit. (note 36).

40 Jiří Čepelák, 'K otázce určení typů vyšší nervové činnosti', Praktický lékař, 33 (1953), 125-30; see also Chertok, op. cit. (note 3), 51.

${ }^{41}$ See, eg. František Havránek, 'Hodnocení výsledků psychoprofylaktické přípravy bezbolestného porodu', Praktický lékař, 33 (1953), 116-18; Vojta, Psychoprofylaktická příprava', op. cit. (note 36).

42 Vojta, 'Psychoprofylaktická prríprava', op. cit. (note 36).

43 Havránek, op. cit. (note 41).

44 Jiří Čepelák, 'Pokus o použití asociačního experimentu při určování typů vyšší nervové činnosti ve vztahu k psychoprofylaxi’, Československá gynaekologie, 18, 32 (1953), 211-22; Čepelák, op. cit. (note 40).

${ }^{45}$ Unfortunately, the author does not provide a reference for these studies; Vojta, 'K otázce odstraňování bolestí', op. cit. (note 36).
} 
maternal care is organised in our country' compared with the USSR, ${ }^{46}$ which explained the poor results of his team by implying the superiority of the Soviets. The six standard Soviet lessons consisted of three parts each: a physiological explanation, physical exercise and the sleep needed to 'fix' what the participants learned during the lesson. ${ }^{47}$ Soviet caregivers trained the expectant mothers in sessions lasting on average 1.5 to 2 hours each. ${ }^{48}$ Their Czech counterparts found that they needed twice or even three times as long to accomplish this task. Vojta's interpretation was that Czech women simply knew less about health issues than their Russian sisters and therefore needed more time to absorb what they had learned. ${ }^{49}$ These courses also revealed that the women needed additional study materials on PPM to 'refresh' what they had heard during the lessons. Vojta thus decided to write what became a popular booklet on PPM for women titled Childbirth without Pain, which was first published in $1953 . .^{50}$

The implementation and study of PPM were rolled out in four phases in 1952, each of which had several objectives and firm deadlines. ${ }^{51}$ The objectives included revising the Soviet version of PPM, preparing preliminary instructions for conducting PPM in a Czechoslovak context, introducing PPM to every kind of clinical setting, training healthcare providers at all institutions in the country and, once provisional instructions had been drawn up, debating them with experts from the Czechoslovak Gynaecological and Obstetrical Society and the Ministry of Health. The ICMC also launched organised training in PPM for physicians and midwives at county maternity hospitals and held lectures and special workshops across the country. ${ }^{52}$ Researchers also experimented with the method, modified it and changed key variables such as the number of participants and classes. In the end, they agreed that PPM should ideally be taught to groups of 10-15 participants per course.

Czech doctors had doubts about a number of aspects of the version of PPM put forward by their Soviet colleagues. They questioned the need for the last part of the lesson, when women were to drift into a sleep that allegedly helped to cement the training and considered it superfluous. ${ }^{53}$ This was the phase in which participants were supposed to enter what many physicians called a semi-hypnotic state, and it was probably the difficulty of inducing this state, and perhaps even the lack of clarity about the exact mechanism by which PPM was supposed to work, that led them to doubt the need for this step. ${ }^{54}$ Moreover, not all doctors in the institute shared Vojta's enthusiasm for and belief in the

46 Vojta, op. cit. (note 28).

${ }^{47}$ Nikolaev, op. cit. (note 3), 58-87; Aurel Hudcovič, 'Psychoprofylaxia a pôrod', Lékárský obzor, 11, 8-9 (1962), 465-8; Lukáš, op. cit. (note 30), 161.

${ }^{48}$ Vojta found that if the principles of the method were to be clear to all the women, then the first class, in particular, would have to be on average 2.05-2.25 hours in length; Vojta, 'Psychoprofylaktická příprava', op. cit. (note 36).

${ }^{49}$ However, Soviet woman was explicitly promoted as a role model in Czechoslovakia in the 1950s, and her relationship to her Czechoslovak 'sister' was deliberately nurtured; Denisa Nečasová, Ženské hnutí v českých zemích 1945-1955 (Brno: Matice Moravská, 2011), 353.

${ }^{50} \mathrm{He}$ also promoted the method in women's magazines and newspapers (eg., in 1951 Zemědělské noviny and Vlasta). Vlasta, one of the most popular women's magazines, published a series of articles on PPM in the 1950s. These were written by Vojta and many other physicians from various health facilities in the country. Many other popular booklets for women were later written by a number of authors.

51 Vojta, op. cit. (note 28).

52 Miroslav Vojta, 'Závěrečná zpráva o výzkumu za rok 1955', \{accession number missing\} (unpublished research report: Ústav pro péči o matku a dítě, Praha); Vojta, 'Psychoprofylaktická příprava', op. cit. (note 36).

${ }^{53}$ Hudcovič, op. cit. (note 47), 465.

54 Vojta, 'Závěrečná zpráva', op. cit. (note 52), 6-8. 
benefits of the method. In May 1952, there was a meeting of all the ICMC's employees and PPM was at the top of the agenda. The final report on the research conducted up to that time, which was written by Vojta and presented at the meeting, revealed that some obstetricians at the ICMC had 'ceased to be interested in getting positive results from the method' and had become sloppy in their application of it. ${ }^{55}$ Vojta blamed those doctors for not adequately strengthening the conditioned reflexes that the women had learned during the PPM classes. He was quick to conclude that the doctors' scepticism was the main reason why the method was not as effective as it was supposed to be. In order to overcome their resistance, the management of the institute decided to make PPM standard protocol and ordered all the institute's physicians to use it.

As the next step in their research, Vojta and his colleagues tried to determine appropriate and objectively measurable criteria for assessing labour pain. The criteria they had been using up to that time had been imprecise, based mainly on physicians' observations of how women behaved during labour and delivery. ${ }^{56}$ They arrived at three sets of criteria: (1) the birthing women's subjective evaluations of pain; (2) objective assessments of the painfulness of labour based on a woman's behaviour; and (3) what methods were administered that proved to be sufficient to alleviate or eliminate labour pain. ${ }^{57}$ Vojta's team was aware that the second criterion was problematic from a scientific point of view, and they tried to find other, more empirically sound, objective criteria to assess labour pain. They experimented with a plethysmograph, which measured pain on the basis of vascular responses; however, this experiment was not successful enough to be taken any further in clinical research. ${ }^{58}$

In accordance with the plan to implement PPM, Vojta arranged special training for selected physicians. ${ }^{59}$ Training was directly funded by the Department of Education at the Ministry of Health, which is indicative of the strong political support that Vojta was able to draw on to promote PPM. This training took place in mid-November 1952. The list of fifteen participating physicians included representatives of the main clinics, maternity hospitals and 'regional institutes of national health' (KÚNZ) in various parts of Czechoslovakia. Soviet Professor P. Chesnakov gave a lecture on the organisation of scientific work in the USSR. Each of the participants presented a paper on a chosen aspect of PPM. Professor Běla Friedländerová, a former top athlete who represented Czechoslovakia in swimming and diving before the Second World War, gave a paper on physical exercises for pregnant and postpartum women. Her contribution was extremely well received. Czechoslovak obstetricians clearly found the physical exercises the most

\footnotetext{
55 Vojta, op. cit. (note 28).

56 They mainly built on observations made by midwives who attended deliveries. The midwives recorded in special charts how 'calm' the birthing woman was, to what extent she cooperated with health-care providers, or any intrusive factors in the environment. Vojta, 'Psychoprofylaktická prríprava', op. cit. (note 36).

57 They worked with an elaborate classification of these criteria. Concerning the first set, they observed the intensity, localisation and 'quality' (kind) of pain. Second, they assessed a woman's behaviour according to a schema to infer whether and to what extent the labour was painful. Third, they recorded what means were enough to reduce pain. These included: deep breathing, massages of lower abdomen, muscle relaxation, pressing painful points, a talk with a midwife or physician who helped the woman to calm down, analgesics and narcotics. Havránek, op. cit. (note 41).

58 A plethysmograph was a device that measured nervous vascular responses during labour. Uterine contractions were identified and recorded by another device - a tocodynamometer. Labour was assessed to be objectively painless when a tocodynamometer demonstrated uterine contractions while a plethysmograph recorded no nervous vascular responses. Havránek, op. cit. (note 41), 117; Vojta, op. cit. (note 52), 5.

59 Vojta, op. cit. (note 28).
} 
appealing part of PPM, even though the original Soviet concept did not include this aspect of preparing for labour to such an extent; ${ }^{60}$ it just covered special breathing practices and training in techniques that could be used to ease labour pain during the 'pushing' phase. ${ }^{61}$ Together with Professor Jiří Trapl, director of the ICMC, Friedländerová proposed a series of 'physical exercises for pregnant women' which were incorporated into PPM courses and became a key pillar of the Czechoslovak version of PPM. ${ }^{62}$ All the papers presented at this workshop were also published in a special issue of the medical journal Praktický lékar [The General Practitioner] in 1953, which promoted the use of PPM among the medical community on the widest possible level. ${ }^{63}$

A substantial number of articles on PPM also appeared in the leading medical journal Czechoslovak Gynaecology, of which Vojta became the editor-in-chief. At the beginning of the decade, books by the founding figures Nikolaev and Vel'vovskii were translated into Czech; the publication of writings by local authors followed shortly afterwards. A considerable number of books and papers were published on PPM. Most of them were papers describing PPM's basic principles on a theoretical level or focusing on its practical aspects. However, there were few actual empirical studies on the efficacy of PPM. I found only two articles that explicitly built on the original research, ${ }^{64}$ but they suffered from many methodological imperfections and were later severely criticised on that basis.

In the early 1950s scientific journals were filled with texts about I.P. Pavlov's work, including papers that tried to link PPM to Pavlov's theory of conditional reflexes. ${ }^{65}$ Štembera divides these articles into several categories. First, he distinguishes studies done by Soviet authors and translated to Czech. Second, there are studies written by the Czech promoters of the psychoprophylactic method of painless childbirth who, for the most part, just rephrased the ideas of the Soviet authors. Third, there are writings that provided information on the practical side of PPM and what women trained in PPM needed in the delivery room. Finally, Štembera refers to the studies that evaluated the success rate of PPM.

The style of writing about PPM changed slightly over the course of the 1950s. Most of the articles published in scientific journals in the second half of the 1950s belong to a genre that I name 'How PPM is practised in our institution'. These articles describe the authors' experiences with PPM in their health-care facilities and usually explain why

60 This interest might have resonated well with an established health culture in the Czech-German tradition which, for instance, stressed the importance of fresh air and physical exercise. Cf., eg., Claire E. Nolte, The Sokol in the Czech Lands to 1914: Training for the Nation (New York: Palgrave Macmillan, 2002); Michael Hau, The Cult of Health and Beauty in Germany: A Social History, 1890-1930 (Chicago: University of Chicago Press, 2003); Anna Fischer-Dückelmanová, Žena lékařkou: lékařská kniha (Wien: Jul. Müller, 1907).

${ }^{61}$ Nikolaev, op. cit. (note 3), 62-84.

62 Karel Balák, 'Provedení profylaktického obratu při poloze koncem pánevním na hlavičku cvičením', Československá gynekologie, 18, 32 (1954), 238-41; M. Vojta et al., 'Psychoprofylaxe a tělocvik - př́iprava na porod', in Z. Štembera (ed.), Deset let boje za zdraví nové generace 1951-1961: Přehled vědecké činnosti Ústavu pro péči o matku a dítě (Praha: Ústav pro péči o matku a dítě, 1961), 31-5.

63 The issue included a preliminary proposal for the Czechoslovak version of PPM; \{Author missing\}, 'Návrh prozatímních instrukcí o psychoprofylaktické přípravě bezbolestného porodu', Praktický lékař, 33 (1953), 136-40.

${ }^{64}$ E. Stiksa, B. Fantová and E. Zvolská, 'Vliv nepř́ijemných emocí u těhotných a rodiček na bolestivost porodu', Československá gynaekologie, 18, 32 (1953), 217-22; Havránek, op. cit. (note 41).

65 For instance, Ladislav Hraško, 'Psychoprofylaktická príprava bezbolestného pôrodu', Lékarský obzor, 33, 4 (1954), 221-4; Vojta, 'K otázce odstraňování bolestí', op. cit. (note 36); Miroslav Vojta, 'Uplatnění pavlovských principů ochranně léčebného režimu v klinice ženských nemocí a v porodnictví’, Československá gynaekologie, 18,32 (1953), 25-36. 
and how the practitioners modified recommendations that were part of the original PPM concept. Most of these papers were of very poor scientific quality and would not meet today's scientific standards. However, they also reveal that almost every institution adopted the PPM instructions in their own original way.

An article by Slovak obstetrician Ladislav Hraško in 1954 is no exception to this tendency towards an imperfect style of scientific writing, ${ }^{66}$ but it is interesting for two reasons. First, it provides an unusually rich theoretical explanation of PPM while comparing it with competing methods, such as hypnosis and Grantly Dick-Read's method of natural childbirth, which was very similar to PPM but was developed in the 1930s. DickRead, a British physician, built on anthropological studies in 'primitive societies' from the late nineteenth century describing painless childbirths among women in 'primitive nations ${ }^{67}$ and concluded that, by nature, childbirth is a painless process. In his view, it was the modern culture of 'civilised' societies that made women scared of childbirth and damaged their innate ability to give birth painlessly. His explanation of birth pain sounded much less 'scientific' than the Pavlovian interpretation that PPM was based on, as he attributed birth pain simply to tensions in the cervix that were caused by fear. ${ }^{68}$ Despite appearing in a number of European languages, Dick-Read's work was never translated into Czech or Slovak. A number of obstetricians in Czechoslovakia criticised his work but rarely referred to his books, giving the impression that they were chiefly parroting the views of their Soviet and French colleagues. ${ }^{69}$

Second, Hraško's article is the only scientific paper that asks how mothers themselves see PPM. In Hraško's view there are three types of women, each of which has a distinct approach to PPM: first, there are "women who have heard about PPM as a ground-breaking achievement of Soviet science and are convinced of its good benefits and therefore ask for it' ${ }^{70}$ Moreover, there are 'uninformed women who have not heard of the method and that is why they take an indifferent and distrustful view of it'. ${ }^{71}$ Third, there are 'women who take a negative view of it and search for news about its failure'. ${ }^{72}$ This categorisation of women into those who either love or hate PPM as a Soviet scientific invention is obviously informed by the dominant ideological interpretation of PPM; it does not actually say anything relevant about real women's perceptions and experiences. I did not find any study that explicitly investigated women's experiences with PPM even though obstetricians at the ICMC recorded women's impressions of their birth experiences and included them as a factor in their general assessment of the method's efficacy and Vojta highly appreciated French obstetrician Fernand Lamaze's interest in women's experience with PPM. ${ }^{73}$ Leftleaning, but never a Communist Party member, Lamaze visited the Soviet Union in 1951 to learn more about PPM. He modified it and made it widely popular in France with

\footnotetext{
${ }^{66}$ Hraško, ibid.

67 Ornella Moscucci, 'Holistic Obstetrics: the Origins of "Natural Childbirth" in Britain', Postgraduate Medical Journal, 79, 929 (2003), 168-73; see also Michaels, op. cit. (note 1), 16-26.

${ }^{68}$ Moscucci, ibid; Michaels, op. cit. (note 1), 19, 38. Dick-Read first described his approach in his book Natural Childbirth (London: William Heinemann, 1933), and later in Childbirth without Fear (New York: Harper \& Brothers, 1944)

${ }^{69}$ For instance, Vojta seems to have never read Dick-Read's work. He mentions his name only in reference to Lamaze's criticism of Dick-Read, about which he learned from his ICMC colleague Kamil Kubát, who visited maternity wards in Paris. Miroslav Vojta, 'K další etapě v úsilí po bezbolestném porodu', 1956 regional conference paper, in M. Vojta, op. cit. (note 36).

${ }^{70}$ Hraško, op. cit. (note 65), 222.

71 Ibid.

72 Ibid.

${ }^{73}$ See, eg., Havránek, op. cit. (note 41); Vojta, 'Závěrečná zpráva', op. cit. (note 52).
} 
the support of women's leftist grassroots organisations. ${ }^{74}$ Among his main innovations, his inclusion of testimony by women about the virtues of PPM during training sessions stands out. ${ }^{75}$ Vojta was greatly impressed by how powerful the birth stories of women who had used PPM were and even recommended following Lamaze's idea of publishing them. But Czechoslovakian obstetricians ignored appeals to investigate women's perspectives on PPM. As their agenda - to make PPM part of socialist health care - did not have to respond to consumers' demands in the same way as in Western countries, there was no urgency or particular incentive to be responsive to any pressures from below.

\section{PPM in a Wider Political Context}

To coincide with the end of the state's first Five-Year Plan, Vojta summarised his team's achievements in a final report. ${ }^{76}$ From 1951 to 1955 he and his team provided training to $10-13$ per cent of the women who came to the ICMC to give birth (approximately 1000 women), using both Vel'vovskii's original PPM concept and their own modified version of it. By 1955, lectures on PPM had been given at forty-two institutes across the country, ten of them following Vel'vovskii's original instructions. A total of 13463 women had participated in PPM courses by that time. This number may be misleading, as it includes women who attended just one lesson, but it is still remarkable, as it reflects how enthusiastically PPM was promoted in the 1950s among health-care professionals and the general public.

Politically, the pursuit of research on PPM proved advantageous because of the method's collectivist ethos and emphasis on the importance of building a new socialist society by transforming society's view of the inevitability of pain in childbirth. Vojta highlighted PPM as 'a method accessible to all women and all health-care providers' ${ }^{77}$ This statement supports Vel'vovskii's argument in favour of PPM ${ }^{78}$ although Vojta does not directly refer to his words. In compliance with the new ethos of celebrating work and the role of the proletariat, Vojta refined the metaphor of labour in the birthing process, stating that: 'The main advantage of psychoprophylactic preparation for childbirth is that a woman cooperates actively during her labour, she comes to the maternity hospital as she would come to work...' ${ }^{79}$ His emphasis on the importance of physical work in childbirth resembles the emphasis that was being put on the importance of physical labour of any kind during these years. The Soviet origin of PPM also allowed him to praise the USSR as a model for Czechoslovak society and science; for example, he wrote:

Medical science never before dared to set such a gigantic task to eliminate labour pains completely. Such a goal could be achieved only by a health-care system that is built on a deep and true human understanding of the individual's responsibilities; that is, by the Soviet health-care system. Achieving the complete elimination of labour pain for all women is the kind of task that only the socialist establishment is able to resolve. ${ }^{80}$

\footnotetext{
${ }^{74}$ Michaels, op. cit. (note 1), 45-55.

75 Lamaze closely collaborated with Pierre Vellay on this issue; Michaels, 'A Chapter from Lamaze History', op. cit. (note 5), 35-6; Michaels (note 1), 55-9.

76 Vojta, 'Závěrečná zpráva', op. cit. (note 52). Following the USSR model, many socialist states centrally directed their economy and planned their economic progress in what were called 'five-year plans'.

77 Vojta,'Psychoprofylaktická příprava', op. cit. (note 36); Vojta, 'K otázce odstraňování bolestî', op. cit. (note 36), 101.

78 Vel'vovskii to M.D. Burova, (1950), TsDAVO (Central State Archive of Ukraine), f. 342, op. 14, spr. 4246, ark. 22ob.

79 Vojta, 'Psychoprofylaktická př́íprava', op. cit. (note 36), 2, 9-10.

${ }^{80} \mathrm{Ibid} ., 7$. This quotation is similar to what Platonov said in a conference paper and what Nikolaev said about the extraordinary potential of the Soviet public health system. Michaels, op. cit. (note 4), 21.
} 
Vojta argued further that the reason why so many Soviet women gave birth painlessly was the general atmosphere of warmth, friendly help and care in the Soviet hospitals. This, of course, was an implicit critique of Czechoslovak health-care workers, but not only of them. Other scholars claimed that 'normal women give birth without any pain', ${ }^{81}$ suggesting that women who felt pain were 'not normal'. In several articles Vojta and others blamed Czech women for listening to 'old-wives' tales' and the backward opinions of other women who had prejudices about childbirth as a painful process. ${ }^{82}$

Reflecting back later on the 1950s, Pařízek, Štembera and other obstetricians pointed out that the dominant ideology of that era uncritically and excessively favoured PPM and exaggerated its analgesic effectiveness, which ultimately led to it eventually being discredited. ${ }^{83}$ Pařízek implies that PPM was favoured at the expense of pharmaceutical methods of pain relief. However, labour-pain medications were considered important and the first Czechoslovak concept of PPM included a whole section on pharmaceutical pain relief methods to be applied if PPM failed. ${ }^{84}$ Research on pharmaceutical methods of pain relief in labour has a long and significant tradition in the Czech lands dating back to the second half of the nineteenth century ${ }^{85}$ and pain relief medications were thus seen as compatible with the principles of PPM. ${ }^{86}$ According to Pavel Čepický, the contingent use of pharmaceuticals was typical for the whole Soviet school of PPM. However, Michaels shows that production shortages in the pharmaceutical industry severely limited the use of anaesthetics and analgesics in obstetric practice in the USSR ${ }^{87}$ Čepický compares Soviet PPM with the Vellay school of PPM in France, which, in his view, applied a neo-psychoanalytical interpretation of the emotional development of the mother-child relationship and saw any medication as having potentially detrimental effects on this fundamental relationship. ${ }^{88}$ Similarly, Michaels argues that psychoanalytical interpretations of labouring women's psychology, as formulated by Freud's disciple Helene Deutsch, significantly influenced French PPM. ${ }^{89}$ She demonstrates that a largely psychological approach to labour-pain management had a special ring of credibility in France, ${ }^{90}$ as it allowed women to stay active and aware during labour while avoiding the harmful side effects of many of the painkilling drugs available at that time, ${ }^{91}$ even though women's attitudes later changed. ${ }^{92}$

Psychoanalysis, as well as its Moravian-born founder Sigmund Freud, was well known and accepted in the Czech lands, ${ }^{93}$ unlike in the USSR, where Freud's ideas were rejected

${ }^{81}$ Zdeněk Štembera, "Stručný obsah přednášek psychoprofylaktické př́ípravy’, Praktický lékař, 33 (1953), 105.

82 Vojta, 'Uplatnění pavlovských principů', op. cit. (note 65), 34; Bohumír Vedra, 'Práce prenatální poradny s hlediska přípravy bezbolestného porodu', Praktický lékař, 33 (1953), 102-3.

83 Pařízek, op. cit. (note 25), 45; Štembera, op. cit. (note 16), 63-5; Pavel Čepický, 'Psychoprofylaktická příprava k porodu', Československá gynekologie, 49, 2 (1984), 119-24.

84 'Návrh prozatímních instrukcí', op. cit. (note 63), 139.

85 Pařízek, op. cit. (note 25), 29-34.

86 Vojta, 'Psychoprofylaktická př́íprava', op. cit. (note 36).

${ }^{87}$ Michaels, op. cit. (note 26), 234.

88 Pavel Čepický, 'Předporodní př́íprava', in A. Pařízek et al., Porodnická analgezie a anestezie (Praha: Grada Publishing, 2002), 201-2.

${ }^{89}$ Michaels, op. cit. (note 1), 4-5.

90 Michaels, 'Comrades in the Labor Room', op. cit. (note 5), 1037.

91 Michaels, 'A Chapter from Lamaze History', op. cit. (note 5).

92 Michaels, op. cit. (note 26).

93 Jiří Hoskovec and Simona Hoskovcová, Malé dějiny české a středoevropské psychologie (Praha: Portál, 2000), 24. 
as incompatible with Pavlovian neuropsychology. ${ }^{94}$ Spreading from Vienna to Leipzig, the region of Central Europe constituted a unique cultural milieu and was where all the important schools of modern psychological science originated. Nevertheless, under Communist rule, the fate and status of the discipline of psychology as a whole worsened, especially in the early 1950s, when it was labelled a 'bourgeois pseudoscience' and classified as a subfield of pedagogy. Surviving at universities with a minimal number of students, the field of psychology became limited to studies of the central nervous system and was thus transformed into the science defined by the ideas of I.P. Pavlov. Many psychologists, especially those with a background in non-Marxian research and theoretical traditions, left academia and went to work in clinical research on health care, which provided them with a freer environment. A number of them also worked at the ICMC, where they mostly studied the cognitive development of early newborns. ${ }^{95}$

\section{The 1960s: the Goals Reformulated}

In the 1960s, Czechoslovak PPM followed a course similar to that in the USSR, but with a delay of approximately ten years. In the Soviet Union, criticism of the method reached a peak in February 1956 at a conference in Kiev, where its outcomes were evaluated five years after its launch. ${ }^{96}$ Conference participants pointed to its many shortcomings, including how time consuming the method was. In that same year, the Soviet Ministry of Health changed the name of the method from the 'psychoprophylaxis of pain in childbirth' to 'psychoprophylactic preparation for childbirth', despite the disapproval of Vel'vovskii and Nikolaev. According to Bell, this move reflected the diminishing official support for the method. ${ }^{97} \mathrm{He}$ also observes that the method was never officially condemned or discarded and maintained its place in official statistics and ministry directives; in practice, however, it lost its appeal.

By contrast, in Czechoslovakia, PPM flourished in practice in the late 1950s and early 1960s. The number of PPM lecturers substantially increased, as the method spread across the country. From 1955 to 1958, only 6 to 7 per cent of pregnant women took part in PPM courses in Czechoslovakia, ${ }^{98}$ but, during 1959, that number increased to 13.5 per cent (1793 women); 260 courses were organised that year, each of them consisting of six lessons. ${ }^{99}$ There were 105 midwives trained in PPM in the country by 1961 and, in every district, there was at least one obstetrician who was trained in PPM. With that level of trained staff, in the early 1960s, it was possible to run PPM courses in almost every maternity hospital. ${ }^{100}$

While PPM expanded in practice, it declined as an object of medical research. Czechoslovak obstetricians showed little scholarly interest in it in the 1960s. The last national conference on psychoprophylaxis in Czechoslovakia took place in $1962 .{ }^{101} \mathrm{In}$ the journal Czechoslovak Gynaecology, only two contributions directly dealing with PPM were published in that entire decade. Only one of them built on empirical research

\footnotetext{
${ }^{94}$ Michaels, op. cit. (note 1), 22: 54.

95 Hoskovec and Hoskovcová, op. cit. (note 93), 24.

96 Bell, op. cit. (note 3), 14; Michaels, 'Comrades in the Labor Room', op. cit. (note 5), 1053.

97 Bell, op. cit. (note 3), 15.

98 Miroslav Vojta, 'Porod bez bolesti', Československá gynaekologie, 25, 4 (1960), 338-40.

${ }^{99}$ Marie Krchová, 'Organizace antenatálního tělocviku a psychoprofylatické př́pravy těhotných k porodu', Československá gynaekologie, 26, 1-2 (1961), 77-8.

100 Ibid.

101 Čepický, op. cit. (note 83).
} 
conducted by Stanislav Trča, an Assistant Professor based at the GynaecologicalObstetrical Clinic in Prague and at the Institute of Health Education. His study examined the effects of the modified version of PPM on the occurrence of prolonged pregnancies. ${ }^{102}$ Among the few publications on PPM published in this decade, Slovak obstetrician Dušan Brucháč's book stands out for its theoretically rich and sophisticated discussion and rigorous description of the applied methodology, which earlier studies on PPM had lacked. ${ }^{103}$ Besides describing a whole PPM course structured into nine lessons, his study presented the results of long-term research on the effects of PPM observed on 784 women trained in psychoprophylaxis and on a control group of 500 women not trained in the method. The findings showed no significant differences in the length and intensity of labour between these two groups except for significantly lower incidence of pre-term births among the women trained in psychoprophylaxis.

In the 1960s, there were more articles published on the subject of antenatal exercises than on PPM per se. I found just a single empirical study on antenatal exercises, written by Jiří Pokorný and Vlasta Václavíková, who investigated the potential effects of their modified version of psychoprophylactic exercises. ${ }^{104}$ Physical exercises came to dominate PPM. ${ }^{105}$ According to Marie Krchová there were sixty-five district organisations that regularly organised classes in antenatal exercises. ${ }^{106}$ Highlighting physical over psychological preparation and the practical aspects of physical training, this shift enabled obstetric nurses to take control of these courses, as they had expertise in the physiology of childbirth and health organisations did not then have to hire university-educated psychologists. This reorientation is also reflected in a number of educational booklets on PPM that were published in the first half of the decade and that were aimed at the obstetric nurses who were running PPM's courses and at pregnant women. ${ }^{107}$ The Central State Institute for Health Education also assisted PPM instructors by publishing brochures on physical education for pregnant women and preparing and distributing visual and audio educational aids and short films with mothers' testimonies about the positive effects of PPM, which were meant to be screened during the classes. ${ }^{108}$

During the 1960s, instructors, nevertheless, became increasingly disillusioned with the promoters' exaggerated claims of completely painless childbirths, as PPM often

102 Stanislav Trča, 'Prodloužené těhotenství a psychoprofylaktická př́íprava $\mathrm{k}$ porodu', Československá gynekologie, 34, 1-2 (1969), 100-1. The second study was a translated paper presenting the results of empirical research on PPM conducted in Dresden, East Germany. R. Ganse, 'K zavádění a výsledkům psychoprofylaktické př́ípravy na bezbolestný porod v klinické praxi’, Československá gynekologie, 28, 7 (1963), 492-5.

103 Brucháč, op. cit. (note 2). Brucháč was based at the Second Gynaecological-Obstetrical Clinic at Comenius University in Bratislava, Slovakia, after receiving research experience at the ICMC in Prague. This clinic was founded by Professor Aurel Hudcovič who attended the ICMC workshop on PPM in 1952 and was the first to introduce and promote PPM in Slovakia. Hudcovič, op. cit. (note 47).

104 Jiří Pokorný and Vlasta Václavíková, 'Hodnocení porodů žen, které prošly psychoprofylaktickou a gymnastickou přípravou v těhotenství', Československá gynekologie, 26, 1-2 (1961), 82-3. However, Vojta also cites other research into the effects of antenatal exercises and, especially, of particular breathing exercises on reducing fatigue during labour that were conducted by Balák, Friedländerová, Štembera and Hodr at the ICMC; Vojta et al., op. cit. (note 62), 31-5.

105 Vojta et al., ibid.; Ita Mokránová, 'Psychická a fyzická príprava tehotných k pôrodu', Zdravotnická pracovnice, 15, 8 (1965), 414-18.

106 Krchová, op. cit. (note 99).

${ }^{107}$ Miroslav Chalupa and Běla Friedländerová, Jak připravit ženu k porodu (Praha: Státní zdravotnické nakladatelství, 1965); Imre Hirschler, Pôrodnica, prosím vstúpte . . L'ahká tehotnosť, úspešný pôrod, zdravé diě̃a (Martin: Obzor, 1965); Rudolf Slunský, Žena a porod. Psychoprofylaktická př́prava k porodu. Tělocvik pro těhotné (Ostrava: Čs. společnost pro šîření politických a vědeckých znalostí, Krajský výbor v Ostravě, 1963).

108 Chalupa and Friedländerová, ibid.; Vojta, op. cit. (note 62), 34. 
failed to deliver on these promises. ${ }^{109}$ Even Vojta recognised that the PPM's main goal of total anaesthetisation was largely unmet. But he located the method's shortcomings not in unrealistic expectations but in the method of pain assessment; in his view, the main problem was that obstetricians, as well as birthing women, assessed painlessness 'universally' in a crude and general way, failing to differentiate among different types or phases of pain. ${ }^{110}$ They ignored various factors at play, such as the causes of pain, the stages of labour and the duration of pain. He argued that the standard of painlessness in childbirth had increased and become more exacting over time, resulting in an impression that the method does not work. ${ }^{111}$ Reflecting on these problems, he proposed to redefine its official goals: instead of ensuring complete painlessness in birth, PPM should aim to prepare women physically and psychologically for childbirth. Accordingly, the official name of the method was changed in 1966 from the 'psychoprophylactic method of painless childbirth' to 'mental and physical preparation for childbirth'. ${ }^{112}$ This choice of words also indicates that physical preparation was considered a significant part of the method, which is especially evident in comparison with the changed Soviet name, which continued to emphasise PPM's anaesthetising effect.

But, in the early 1960s, Vojta's word did not carry the same weight as it had in the previous decade. Perhaps out of ideological motivations, Vojta, as head of the ICMC in the late 1950s, decided to curb research in some promising areas of endocrinology, bringing him into conflict with its Scientific Advisory Board. He prohibited the publication of original research by ICMC researchers in leading Western journals despite the fact that such articles could have earned the institution international recognition. ${ }^{113}$ The Scientific Board and the Advisory Committee opposed his decisions and submitted a request to the Minister of Health to dismiss Vojta from his position as director of the ICMC. According to Štembera, who led the ICMC's trade union committee that was seeking Vojta's dismissal, severe conflicts at the ICMC led the Minister of Health to ask for advice from the Soviet minister of health. The Soviet minister sent Professor Pavel Andreevich Beloshapko, the USSR chief obstetrician-gynaecologist at the Ministry of Health, ${ }^{114}$ to Prague to analyse the situation. Beloshapko recommended dismissing Vojta from his position and the Czechoslovakian Minister of Health did so in 1963. At the same time, paediatrician Kubát also left the ICMC. Štembera glosses over this with a remark that 'as a consequence of these changes dialectical materialism and Marxist ideology stopped influencing scientific activities at the institute'. ${ }^{115}$

This was, indeed, the beginning of what many perceived as a new era. After twenty years, Czechoslovakia finally seemed to be gaining freedom from the overbearing influence that the Soviet Union had wielded over it since the end of the Second World War. Czechoslovakia, like other countries in Central, Southern and Eastern Europe, experienced similar tendencies in their post-war development, often described as 'Sovietisation'. This

\footnotetext{
109 See Mokránová, op. cit. (note 105); Štembera, op. cit. (note 16), 127.

110 Miroslav Vojta, 'Prevence vzniku bolesti při porodu', Československá gynekologie, 28, 7 (1963), $495-8$.

111 Ibid., 496.

112 Stanislav Trča, Psychická a fyzická př́prava těhotných žen k porodu (Praha: Ministerstvo zdravotnictví, Ústav zdravotní výchovy, 1966), 6.

113 Vojta found research into the endocrinology of gestation incompatible with I.P. Pavlov's CNS doctrine, while arguing that, in the USSR, all the endocrinology laboratories had been shut down. Štembera, op. cit. (note 16), $76,127-8$.

114 Michaels, op. cit. (note 1), 79.

115 Štembera, op. cit. (note 16), 128.
} 
term refers to the process by which political alternatives were gradually restricted until the political regime was turned into a restricted pluralist system or - more frequently a Stalinist dictatorship. Sovietisation differed widely across the region in its form and timing, often involving Soviet military presence, which exerted powerful political pressure on local governments. ${ }^{116}$ It generally had severe consequences on culture, science and social lives in the countries it affected.

In the second half of the 1960s, obstetricians and gynaecologists became preoccupied with new topics that they found more interesting than PPM. More importantly, the Prague Spring and the political liberation it ushered in loomed on the horizon and opening up new opportunities. Czechoslovak researchers began to be allowed to publish their work in Western journals, to cooperate with prominent institutions in the West and to participate in international symposiums abroad. ${ }^{117}$ Stembera notes that scientific associations also began to have more say in who participated in international conferences than before. The Ministry of Internal Affairs also gave the Czechoslovak Gynaecological and Obstetrical Society permission to organise an international symposium on intrauterine foetal development in Prague in October 1966. The programme featured 106 papers presented by local and foreign experts from both socialist and Western countries. ${ }^{118}$ Many participants had international reputations, making the symposium a highlight of the decade.

\section{The 1970s and 1980s: ‘Normalisation’ and PPM's Rebirth}

Following the suppression of the Prague Spring in August 1968, the subsequent era of what came to be called normalisation disrupted the process of fully integrating Czechoslovakians into the international community of scholars, as cooperation with Western institutions was curtailed. Vojta again rose to the forefront of the gynaecologicalobstetrical community and the articles he published in gynaecological journals on political occasions exhibit the requisite political ethos. ${ }^{119}$ But, in part due to Vojta's death in 1974, the issue of PPM did not return to the pages of medical journals. The only notable work published on the subject in this decade was a short booklet by Trča providing advice on how to run PPM courses. ${ }^{120}$

In the 1970s, psychoprophylaxis existed as 'a mere column in statistical reports' with little relationship to real practice. ${ }^{121}$ In research, as well as in clinical practice, it seemed dead. ${ }^{122}$ Nevertheless, this was not the end of the story.

In 1984, the psychoprophylactic method celebrated a comeback on the pages of Czechoslovak Gynaecology. This was mainly the work of the ICMC's Dr Čepický and his

\footnotetext{
116 J. Vykoukal, B. Litera and M. Tejchman, Východ: Vznik, vývoj a rozpad sovětského bloku 1944-1989 (Praha: Nakladatelství Libri, 2000), 95-101. See also B. Apor, P. Apor and E.A. Rees (eds), The Sovietization of Eastern Europe: New Perspectives on the Postwar Period (Washington: New Academia Publishing, 2008).

117 Stembera, op. cit. (note 16), 155-6.

118 Ibid., 135-42.

119 Ibid., 158-61.

${ }^{120}$ Stanislav Trča, Duševní a tělesná př́prava těhotné ženy $k$ porodu, Edn Metodické listy (Praha: Ústav zdravotní výchovy, 1974).

121 P. Čepický, K. Ludvíková and A. Mellanová, 'Současný stav porodnické psychoprofylaxe v Praze I. Způsob provádění přípravy’, Československá gynekologie, 49, 8 (1984), 568-72.

122 Yet, in 1972, prominent Slovak psychologist and psychotherapist Ondrej Kondáš and his student Božena Ščetnická published a much quoted contribution to the international debate about the efficacy of PPM. Ondrej Kondáš and Božena Ščetnická, 'Systematic Desensitization as a Method of Preparation for Childbirth', Journal of Behavior Therapy and Experimental Psychiatry, 3 (1972), 51-4. However, the study did not appear in any local journals and thus had no impact on the debate in Czechoslovakia.
} 
colleagues and students who published a series of articles on PPM during this decade that initiated a heated debate on the issue. They conducted research on PPM's effects among ninety-four women who gave birth in the Second Gynaecological-Obstetrical Clinic in Prague. They also examined the state of practice of PPM in the Prague region based on interviews with PPM course instructors in nine of the city's ten districts. They came to the dismal conclusion that, in most districts, the practice of PPM violated the method's basic principles. ${ }^{123}$ The courses had been shortened and simplified; moreover, the majority of pregnant women did not even undergo a shortened version of the PPM course, although official statistics stated the opposite. Most women only attended a two-hour long 'mass' lecture.

A sharp reaction from medical and public health authorities to this publication quickly followed. Jitka Kobilková, the head of the Second Gynaecological-Obstetrical Clinic, together with Václav Trnka, a leading expert in obstetrics, communicated the position of the Regional Advisory Board on this view which reflected that of the majority of Prague obstetricians. ${ }^{124}$ They denounced the piece as 'unscientific' for its methodological weaknesses, arguing that Čepický's research sample was not representative and the findings were thus misleading. Kobilková and Trnka write in an enraged tone, as if Čepický's critical review were a personal affront meant to discredit these senior experts. Furthermore, they accused Čepický and his co-authors of arrogance for daring to evaluate the current state of PPM without first consulting with the regional gynaecological board. The journal's editorial board was not spared their fury either, as Kobilková and Trnka accused the editors of publishing the article without the authorities' approval.

Čepický and his co-authors responded in an apologetic tone that emphasised their deepest respect for Kobilková's and Trnka's expertise and sought to explain 'the misunderstanding'. ${ }^{125}$ They had not designed their study as a representative survey, but rather as an initial empirical probe into the everyday practices of PPM. They believed that the bleak situation in the Prague districts was symptomatic of the whole country and that PPM had faded into obscurity and needed to be revived. Čepický took a particularly critical stand against the 'classic' Czechoslovak studies of the 1950s, pointing to their numerous methodological shortcomings, such as failing to use control groups or the placebo technique. ${ }^{126}$ Like earlier authors, he argued that the standards of quality had declined after an initial enthusiasm, leading to the poor results and the method's discredit. ${ }^{127}$

The articles on PPM published in Czechoslovak Gynaecology were based on research by Květa Ludvíková, a midwife who worked in the early 1980s with Dr Čepický in the Prague Gynaecological-Obstetrical Clinic, informally known as 'Apolinář' ${ }^{128}$ Aspiring to complete a university degree, she started studying in a new programme in 'patient care' at Prague's Charles University and decided to investigate birthing women's experiences and behaviour because she 'did not like the kind of childbirth management [she] saw in

\footnotetext{
123 Čepický et al., op. cit. (note 121).

124 Jitka Kobilková and Václav Trnka, 'Současný stav porodnické psychoprofylaxe v Praze I. Způsob provádění přípravy. Diskusní příspěvek k článku dr. P. Čepického et al.', Československá gynekologie, 50, 3 (1985), 227-8. 125 Pavel Čepický and Květa Ludvíková, 'Odpověd̆ a vysvětlení prof. MUDr. J. Kobilkové, DrSc. a prof. MUDr. V. Trnkovi, DrSc. a malá poznámka M. Pečené’, Československá gynekologie, 50, 3 (1985), 229-30.

126 Čepický, op. cit. (note 83).

127 Ibid., 119.

128 Květa Ludvíková, 'Vliv psychoprofylaktické přípravy na prožívání porodu’ (unpublished MA thesis: Faculty of Philosophy, Charles University in Prague, 1984).
} 
maternity hospitals'. ${ }^{129}$ She asked Dr Čepický to supervise her master's thesis, as his main research interest - psychosomatics - was related to the topic. He agreed to work with her on the project while using it as an opportunity to fulfil the publication obligations placed on him by the ICMC, his new employer.

In the process of contacting PPM course instructors in Prague city districts, Ludvíková met Dr Marie Pečená, a psychologist with a background in midwifery. According to Čepický, Pečená initiated the PPM renaissance in the early 1980s. She was one of the few graduates of a special high school programme in midwifery that was opened in the mid-1970s. During her programme of internship in a maternity hospital, she witnessed an authoritarian, paternalistic and moralising approach to women as 'objects' of medical care, which she did not like. While her classmates and other obstetric nurses enjoyed coffee in the break room, she ran around the ward with a pen and a piece of paper sketching uteruses and ovaries and explaining what was happening in their bodies to women who were interested. In an interview I conducted with her in March 2012 she recalled:

... I found that these women were seeking me out so they could stop me and ask me a whole lot of questions, and I found it really sad that they had to wait for an enthusiastic high school student to get these answers, and that this was not a common practice that they were entitled to. ${ }^{130}$

At the age of sixteen, she was concerned about how to help and calm down women who were scared of childbirth. She wondered what she could do about the way in which women were treated and was worried that doctors and nurses did not pay any attention to 'the psychological aspect of the care provided'. She realised that it was important for her to nurture 'a nice relationship - one of respect for a woman'. From the beginning, she thus knew that she needed to 'do something good for these women'. ${ }^{131}$ At the same time she believed that:

There must be some kind of prevention that could somehow turn this into something else and bring these people together in a different way, so that their encounter is a harmonious one and this exactly is what can lead to a good outcome.

Her vague idea of 'prevention' started to take firmer shape as the social and political climate began to change slightly and 'people didn't feel like being dragged along by what someone else wanted anymore, even though he was the expert, right?' ${ }^{32}$ As Michal Pullman has shown, from the end of the 1970s, there began to be more and more room for diverse values, demands, attitudes and interests, which thus created the potential for societal change. ${ }^{133}$

Fascinated by the psychological aspects of care, Pečená started to study psychology at Charles University and, coincidentally, she became pregnant in her first year of study, giving her the opportunity to experience the system from the other side. Despite being a midwife by education, she was surprised by the lack of information offered to patients about the practical aspects of pregnancy, childbirth and birth care. This led her to the decision to write her master's thesis on the psychoprophylactic method. She conducted empirical research with seventy-nine women contacted through antenatal care units; only twenty-three of the subjects participated in her PPM course, in which she tried to apply

\footnotetext{
129 In-depth interview with K. Ludvíková (March 2013, Prague).

${ }^{130}$ In-depth interview with Dr Pečená (March 2012, Prague).

131 Ibid.

132 Ibid.

133 Michal Pullman, Konec experimentu: přestavba a pád komunismu v Československu (Praha: Scriptorium, 2011), 21.
} 
as individualised an approach as possible and to promote an active attitude to the birthing process. She built on her own observations of the labour and delivery of all the participants and drew up questionnaires in which midwives and women could evaluate their birth experiences. She also developed a questionnaire to assess the pain thresholds of individual women in the research sample. In this way, she was able to find out how much the women believed in their ability to overcome pain or any obstacles in the delivery process. Her main finding was that there was indeed a difference in the experience of labour between women in the control group and women who had been trained in PPM. Women with PPM training had a significantly shorter labour. Pečená infers that PPM reinforced women's belief in themselves and their own strength; thanks to physical exercises they were able to assess their own capabilities more accurately and spend their energy more effectively. ${ }^{134}$

Pečená continued to run PPM courses and prenatal exercises at five different places in Prague as an employee of the OÚNZ of Prague district 4 after her graduation in 1979. These became a huge success and were attended by women from all around the city, including many female physicians and nurses. During the next eight years (1980-88), she managed to substantially extend her PPM courses, integrating new methods of relaxation and desensitisation of pain, massages, acupressure and various psychological techniques, so transforming the course into a kind of group psychotherapy. In her hands, PPM was turned into an approach that reflected the importance of respect and dignity for 'the other' in health care. ${ }^{135}$ It was no longer just about providing women with information about childbirth issues.

Like Čepický, Pečená also firmly believed that PPM could be an effective method for overcoming fear and anxiety, which negatively affected the course of labour. With degrees in both gynaecology and psychology, Čepický particularly stressed the psychological aspects of providing care and promoted psychologists or psychotherapists as the main PPM instructors. At the same time, he emphasised the emotional needs of birthing women over the material and technical ones (such as the design of delivery rooms), which seemed difficult to change at that time because of financial constraints. Yet he observed that highly individualised care could not be provided to all women on a daily basis because doing so was very demanding; only those who needed it most could get it, he argued. Unlike Vojta, who emphasised the democratising potential of PPM in the 1950s, Čepický now advocated a differentiated approach to providing the appropriate form of the PPM, arguing that it was a common practice in 'other countries' ${ }^{136}$ His appeal came several years before the argument for more individualised and commercialised (ie. private) health-care services emerged in the post-socialist era as part of the political discourse in the 1990s.

Čepický, however, argued that PPM must be based on sound empirical research and, for this purpose, he set about researching PPM's efficacy. ${ }^{137}$ His research team conducted a large empirical study, the aim of which was to distinguish and measure the 'specific' and 'non-specific' (placebo) effects of PPM. The findings indicated that all the research groups that went through some kind of preparation for childbirth had better childbirth outcomes (eg. in terms of the length of labour and of the particular stages of labour, the need for medication and the weight of the newborn) than the group that had none,

\footnotetext{
134 Marie Pečená, 'Otázky psychoprofylaktické př́ípravy těhotných žen k porodu' (unpublished MA thesis: Faculty of Philosophy, Charles University in Prague, 1979).

135 In-depth interview with Dr Pečená (March 2012, Prague).

136 Čepický, op. cit. (note 83), 121.

137 Ibid., 122.
} 
while the differences between the groups according to the different kinds of preparation for childbirth were not so significant. ${ }^{138}$

In the revolutionary year 1989, Dr Čepický approached Dr Pečená with a special offer to co-found a psychosomatic laboratory that would be attached to the gynaecology ward at the ICMC. Both of them believed that this laboratory would be unique worldwide for its focus. Dr Pečená recalls her time in this laboratory as a creative period full of exciting projects and ideas. ${ }^{139}$ This feeling was amplified by the post-revolutionary mood of enthusiasm and anticipation. Čepický and Pečená formed - in their words - a 'dream team'. While Pečená loved 'to create things with people in situ' and was practical, Čepický was a rigorous academic who was under an obligation to publish the results of his work. ${ }^{140}$ It seems that it was the unique cooperation with Dr Čepický that made it possible for Pečená's ideas - implemented in practice in the city's districts - to find their way into writing and publication as a new PPM Concept.

According to Čepický it was Eva Ettrichová who initiated the process of converting the new PPM Concept into a written course outline, including lesson content and instructor guidelines, so that the Concept could be issued as an official recommendation by the Ministry of Health. ${ }^{141}$ Eva Ettrichová was an employee at one of the state institutes of preventive medicine and health education but, more importantly, she had close personal ties to a high-level official at the Ministry of Health. As a result of her efforts, a committee was set up to draw up a formal version of the new PPM Concept for instructors; the committee's members included Marie Pečená, Marcela Bendová, Ilona Kotátková and others who were also involved in the Psychosomatic Committee of the Czechoslovak Gynaecological and Obstetrical Society. ${ }^{142}$ According to Dr Čepický:

The vision was that it was going to be written down, and Professor Břešták, the head of the clinic on the Londýnská Street [in Prague], would then recommend it as an official guideline to a minister. (... ) But before they were able to put this into practice at the ministry, November 1989 arrived, and everything changed after that!

The Concept never achieved the status of an official guideline sanctioned by the Ministry of Health, but it was published in Czechoslovak Gynaecology in May $1990 .{ }^{143}$ It broadened and redefined goals of the psychoprophylactic method - now simply called 'the preparation of pregnant women for childbirth'. It proposed that, unlike the 'classic versions of PPM', 'modern' preparation for childbirth should not aim to eradicate pain but should instead seek to help women to cope with new feelings of pain and accept them as part of the process. ${ }^{144}$ Women needed to learn how to adopt a 'realistic' attitude to childbirth and, therefore, they needed to be prepared for the possibility of obstetrical complications and the medical management of childbirth, too. The substantial modification of the goals of PPM, however, did not mean that the 'preparation of pregnant women for childbirth'

\footnotetext{
${ }^{138}$ Unfortunately, besides a short theoretical piece on the placebo technique [P. Čepický and B. Čepická, 'Placebová technika porodnické psychoprofylaxe', Československá gynekologie, 49, 7 (1984), 520-1], the study has never been published, as one of the research team's members lent the final results of the research to a student who lost the only copy. In-depth interviews with Dr Čepický (November 2011, Prague) and Dr Pečená (March 2012, Prague).

139 In-depth interview with Dr Pečená (March 2012, Prague).

140 Ibid.

${ }^{141}$ In-depth interview with Dr Čepický (November 2011, Prague).

142 Pavel Čepický, 'Psychosomatické aspekty gynekologie a porodnictví' (unpublished PhD thesis: Ústav pro péči o matku a dítě, 1997), 352.

143 Marie Pečená et al., 'Koncepce př́ípravy těhotných žen k porodu', Československá gynekologie, 55, 10 (1990), 769-73.

144 Ibid., 770.
} 
turned to favouring medical interventions. The concept still stressed that women needed to be informed about 'alternative' methods of pain relief, such as acupressure, massages or yoga, and alternative forms of childbirth management. ${ }^{145}$ PPM has never regained its previous heights, even though the new concept seemed to motivate some practitioners to promote changes in the way PPM was being practised. ${ }^{146}$ The events that took place after November 1989 opened up many new opportunities, which obstetricians and midwives explored. Dr Pečená extended the scope of prenatal education: she offered and started to organise courses for midwives to teach them her version of PPM. A number of the participants in these courses went on to become key figures in promoting changes in midwifery and the birth-care system as a whole. The fall of the Iron Curtain and the opening of the borders also allowed new ideas from the West, including ideas relating to childbirth education, to flow more freely into the Czech environment.

\section{Conclusion}

The Czechoslovak psychoprophylactic method of painless childbirth was imported from the Soviet Union in the early 1950s as a form of political propaganda and demonstration of ideological fealty. While in the USSR it offered a much welcome solution to the shortages in the pharmaceutical industry, Czechoslovakians were not faced with such shortages and were able to experiment with various kinds of pharmaceutical pain relief. In Czechoslovakia, PPM was promoted for political reasons and was part of the 'Sovietisation' of local science. Czechoslovakians made important modifications to the method, a sign that within the Soviet bloc psychoprophylactic practice was implemented thoughtfully and critically and with an eye towards national specificities. But this independence should not be overstated. For the most part, the Czechoslovakians conformed to the Soviet model: the intense promotion of PPM in the 1950s was followed by criticism in the 1960s and the method's de facto abandonment in the 1970s. In the 1980s PPM began a new stage in its history in Czechoslovakia thanks to the activism of a few enthusiasts, mostly midwives and psychologists, who were unhappy with the depersonalisation and indifference of socialist birth care. They pointed to defects in the contemporary system and started to make changes. This handful of enthusiasts managed to transform PPM from a method of labour-pain prevention into a holistic philosophy. Surprisingly, this turn happened at the same time as a shift in psychoprophylactic practice was also occurring in the United States, where advocates of this kind of approach turned their attention to the Lamaze method as a philosophy promoting more natural, less interventionist birth practices. ${ }^{147}$

There were other ways in which the Czechoslovak version of PPM oscillated between the East and West. Čepický was envisaging the existence of a differentiated and individualised form of birth care in Czechoslovakia - associated in the post-socialist era with the capitalist West - several years before any such system was even a feasible idea, let alone potential reality. The activism of these enthusiasts was not, however, defined in political terms; these individuals did not view their activities as being 'against the regime'. Their efforts grew out of an attitude that was widely shared in the late socialist era. As

145 Ibid., 772.

146 At least that is what a brief announcement published in Czechoslovak Gynaecology suggests. L. Jasioková and N. Zbořilová, 'Náplň školícího místa pro psychologickou přípravu k porodu', Československá gynekologie, 55, 6 (1990), 462-3.

147 Michaels, op. cit. (note 1), 146. 
Pullman suggests, first and foremost people were concerned with living normal lives, and it was 'according to their normal lives and the values they nurtured in them, that they judged the condition of the socialist regime ${ }^{\prime 148}$ - in so far at least as they could do so and remain 'non-political' and not question basic ideological principles. ${ }^{149}$

However indicative the history of psychoprophylaxis in Czechoslovakia is of the wider social and political forces that shape maternity care, it is important to acknowledge that PPM has never been a priority on the research agenda in Czechoslovak gynaecology and obstetrics, even in the years when it was being vigorously promoted nationwide. Gynaecologists and obstetricians in state-socialist Czechoslovakia were primarily interested in and researched problems such as perinatal and maternal mortality, the treatment of birth trauma and obstetrical pathologies, and it was the study of these issues that shaped Czechoslovakian perinatology and earned it international fame. ${ }^{150}$ That fame then faded after 1968 when most of the renowned experts in this field were forced out of the ICMC for political reasons. ${ }^{151}$

In this article, I have reconstructed the history of the PPM as a special method of antenatal and birth care that underwent significant transformations over time. Contingent on political context and on the position, proclivities and fate of its champions, not only did the name of this method change repeatedly but also its content. There is, nevertheless, a certain continuity at its core by which it remains the same even as it shifts. PPM appears to be a fluid object of scientific inquiry. According to Law and Singleton, a fluid object differs from more conventional objects of scientific inquiry because it does not have an immutable shape or name. 'Oxymoronically, it is something that both changes and stays the same.' 152 The practice of psychoprophylaxis exhibits cohesion across national boundaries, yet yields to adaptation in each national setting. It retains enough of its essential form to allow for comparisons of how it is practised in different places, but any such analyses must equally take into account local actors and conditions. It is an object that allows historians and social scientists of medicine to shed light on key cultural and political aspects of obstetrical practices and analyse their continuity and discontinuity across different historical and societal contexts. By providing insight into the rich configuration of meanings that are attached to childbirth and birth care, it reveals how deeply cultured a phenomenon obstetrics truly is.

\footnotetext{
148 Pullman, op. cit. (note 133), 16.

149 Ibid., 21.

${ }^{150}$ In-depth interview with Dr Čepický (November 2011, Prague); Štembera, op. cit. (note 16), 140.

151 Štembera, op. cit. (note 16), 159-60.

152 John Law and Vicky Singleton, 'Object Lessons', Organization, 12, 3 (2005), 338.
} 